\title{
Sea ice extent and seasonality for the Early Pliocene northern Weddell Sea
}

Mark Williams, ${ }^{\mathrm{a}, \mathrm{b},{ }^{*}}$, Anna E. Nelson ${ }^{\mathrm{c}}$, John L. Smellie ${ }^{\mathrm{a}, \mathrm{c}}$, Melanie J. Leng ${ }^{\mathrm{d}}$, Andrew L.A. Johnson ${ }^{\mathrm{e}}$, Daniel R. Jarram ${ }^{\mathrm{a}}$, Alan M. Haywood ${ }^{\mathrm{f}}$, Victoria L. Peck ${ }^{\mathrm{c}}$, Jan Zalasiewicz ${ }^{\mathrm{a}}$, Carys Bennett ${ }^{\mathrm{a}}$, Bernd

R. Schöne ${ }^{g}$

${ }^{a}$ Department of Geology, University of Leicester, Leicester, LE1 7RH, UK

${ }^{b}$ British Geological Survey, Keyworth, Nottingham, NG12 5GG, UK

${ }^{c}$ British Antarctic Survey, Geological Sciences Division, High Cross, Madingley Road, Cambridge, CB3

OET, UK

${ }^{d}$ NERC Isotope Geosciences Laboratory, British Geological Survey, Keyworth, Nottingham, NG12 5GG, UK ${ }^{e}$ Geographical, Earth and Environmental Sciences, School of Science, University of Derby, Kedleston Road, Derby, DE22 1GB, UK

${ }^{f}$ School of Earth and Environment, University of Leeds, Leeds, LS2 9JT, UK

${ }^{g}$ Department of Applied and Analytical Palaeontology, Earth System Science Research Centre, Institute of Geosciences, University of Mainz, Johann-Joachim-Becherweg 21, 55127 Mainz, Germany

*Corresponding author. E-mail address: mri@le.ac.uk (M. Williams)

\section{Abstract}

Growth increment analysis coupled with stable isotopic data $\left(\delta^{18} \mathrm{O} / \delta^{13} \mathrm{C}\right)$ from Early Pliocene (ca 4.7 Ma) Austrochlamys anderssoni from shallow marine sediments of the Cockburn Island Formation, northern Antarctic Peninsula, suggest these bivalves grew through much of the year, even during the coldest parts of winter recorded in the shells. The high frequency fluctuation in growth increment width of $A$. anderssoni appears to reflect periodic, but year-round, agitation of the water column enhancing benthic food supply from organic detritus. This suggests that Austrochlamys favoured waters that were largely sea ice free. Our data support interpretation of the Cockburn Island Formation as an interglacial marine deposit and the previous hypothesis that Austrochlamys retreated from the Antarctic as sea ice extent expanded, this transition occurring during climate cooling in the Late Pliocene. Our data question climate models that show extensive sea ice in the Weddell Sea during the Early Pliocene.

Keywords: Pliocene, Antarctic, bivalves, seasonality, sea ice, climate 


\section{Introduction}

31 The Pliocene Epoch (5.3 to $2.6 \mathrm{Ma}$ ) spans a time when the Earth experienced a transition from relatively warm conditions to a cooling climate that heralded the high magnitude glacial-interglacial oscillations of the Pleistocene Epoch (Haywood et al., 2009). The warm interglacial climates of the Pliocene may be plausible comparative scenarios for interpreting the path of future climate warming during the $21^{\text {st }}$ century (Jansen et al., 2007; Haywood et al., 2009). Whilst overall global climate may have been $2-3^{\circ} \mathrm{C}$ warmer during the 'mid Piacenzian warm interval' (= 'mid Pliocene warm period' of earlier papers), climate at high latitudes is modelled to have been much warmer than today (Haywood et al., 2007 and references therein). Given the significance of a warming $21^{\text {st }}$ century global climate and its influence on high latitude sea surface temperatures and sea ice extent, it is important to develop proxies that can ground-truth models of high latitude regions during the 41 Pliocene (e.g. Dowsett, 2007, fig. 6).

Bivalves preserve a signal of marine seasonality (e.g. water temperature, upwelling, food supply) in their carbonate geochemistry and skeletal morphology (e.g. Jones and Quitmyer, 1996; A. Johnson et al., 2000, 2009; Schöne et al., 2003, 2005). These signals have been used to provide climate information across a range of palaeolatitudes (e.g. Williams et al., 2009a). Antarctic seasonality. Nevertheless, Berkman et al. (2004) have presented a cogent argument, based on morphological and sedimentological analyses, which suggests that the retreat of Chlamys-like bivalves from the Antarctic resulted from increasing sea ice cover during the climate cooling of the

51 Late Pliocene.

The pectinid bivalve Austrochlamys anderssoni occurs commonly in rocks of Late Miocene through Pliocene age on the northern Antarctic Peninsula. Austrochlamys anderssoni is ideal for investigation of palaeoseasonality as specimens are large, often reaching greater than $10 \mathrm{~cm}$ from 
umbo to margin in adults, and record a number of seasons of growth. In addition, the width of individual growth increments in $A$. anderssoni is easy to measure (mm-scale), and they are correspondingly easy to sample for geochemical analysis. Here we analyze ontogenetic patterns in A. anderssoni to test for the extent of sea ice in the northern Weddell Sea during a warm interval of the Early Pliocene. We test two possible marine scenarios: 1), that there was extensive winter sea ice with no planktonic food-supply, no re-suspension of detrital food and therefore limited or no bivalve growth, an environment suggested by some climate models (see Fig. 1); and 2), no winter sea ice with bivalve growth continuing via a supply of periodically re-suspended organic detritus via water column agitation. We use stable oxygen and carbon isotopes to define seasonal intervals during the growth of $A$. anderssoni and to estimate seasonal temperature variation: we then use growth increment data as a proxy to interpret benthic food supply and sea ice extent.

\section{Geological setting}

The James Ross Island Volcanic Group (JRIVG) dominates the outcrop geology of James Ross Island, Vega Island and several small islands including Cockburn Island, in the northern Weddell Sea, east of the Antarctic Peninsula (Fig. 2). The volcanic rocks unconformably overlie relatively unconsolidated Cretaceous marine deposits. About 10 million years of late Neogene and Quaternary history is recorded in the JRIVG (Smellie et al., 2006a, b, 2007, 2008, 2009; Hambrey et al., 2008). Sedimentary rocks in the JRIVG are dominated by diamictite conglomerate and minor sandstone (Smellie et al., 2006a; Hambrey et al., 2008; Nelson et al., 2009). Two sedimentary formations have been defined, the interglacial marine Cockburn Island Formation (Jonkers, 1998a, b) and the glacial Hobbs Glacier Formation (Pirrie et al., 1997). Fossils have been recovered from both of these formations, and in addition rare asterozoan trace fossils are preserved in marine-deposited volcanic tuffs (Williams et al., 2006; Nelson et al., 2008). The JRIVG represents an important and largely unexploited archive of late Neogene fossil and geochemical data for reconstructing past climate and seasonal regimes at high southern latitude. 
The richest Neogene fossil assemblages in the JRIVG are those of the interglacial marine

Cockburn Island Formation, which contains abundant large molluscs, especially Austrochlamys ('Zygochlamys' of Jonkers et al., 2002; see Jonkers, 2003 for a detailed taxonomic appraisal). The glacimarine deposits of the Hobbs Glacier Formation contain similar macrofossil assemblages, are dominated by molluscs (including Austrochlamys), but also contain older material reworked from the Cretaceous (Smellie et al., 2006a). Collectively these fossils occur in strata of Late Miocene (ca $6 \mathrm{Ma}$ ) through to Pleistocene age (ca $2 \mathrm{Ma}$ ). Detailed analysis of the JRIVG has identified three intervals of relative warmth in the northern Peninsula region, when volcanic rocks were erupted into a marine environment (Smellie et al., 2006a, fig. 6). Radiometric $\left({ }^{40} \mathrm{Ar} /{ }^{39} \mathrm{Ar}\right.$ ) dates from the volcanic rocks, together with ${ }^{87} \mathrm{Sr} /{ }^{86} \mathrm{Sr}$ chronology from the molluscs in the intervening glacimarine and interglacial marine rocks have produced a well-resolved stratigraphy which constrains the warm intervals to 6.5 to $5.9,5.03$ to 4.22 , and ca 0.88 Ma. The Austrochlamys material we study here, from the second of these warm intervals, is dated at $4.66+0.17 /-0.24$ Ma by McArthur et al. (2006).

\section{Provenance of bivalve material on Cockburn Island}

The Austrochlamys bivalve material is sourced from three localities on the east side of Cockburn Island referred to in BAS archives as DJ.851, DJ.852 and DJ.853 (Fig. 2). This material was collected by H.A. Jonkers in 1996 though the island had been visited on several occasions dating back to 1906 (Jonkers, 1998a). The Cockburn Island Formation forms small outcrops at a number of localities on the island and Jonkers recognised a western 'proximal' or 'littoral' facies and an eastern 'distal' facies. Based on the gradient atop the island he estimated the latter, bivalve-bearing facies to represent original water depths no greater than $100 \mathrm{~m}$. Fossils associated with the bivalves include echinoids, gastropods, brachiopods, serpulids and rare possible penguin bones. The precise stratigraphical relationships of the bivalve material from the three localities documented here is difficult to discern, but they are clearly from the same substratum. 


\section{Austrochlamys as a palaeoenvironmental index of Antarctic shelf waters in the late Neogene}

Austrochlamys is an epibenthic pectinid bivalve genus comprising six species whose distribution is restricted to the Antarctic and sub-Antarctic region, with one extant species known from South America (Jonkers, 2003; Quilty et al., 2004). The earliest Austrochlamys occur in Oligocene deposits of King George Island (for a summary of fossil occurrences see Berkman et al., 2004). Sub-fossil material is also known from as far north as southern New Zealand (Auckland Islands, Dijkstra and Marshall, 2008). Fossils of Austrochlamys are prolific and widespread in strata of Late Miocene through Pliocene age of the Hobbs Glacier and Cockburn Island formations and often are very well preserved (Fig. 3), with specimens articulated even when they occur in glacimarine deposits (Nelson et al., 2009). Jonkers et al. (2002) believed this was a function of minimal transport with the bivalves preserved virtually in situ. Austrochlamys of the Hobbs Glacier and Cockburn Island formations belong to the species A. anderssoni (see Jonkers, 2003), thought to be a byssally attached epibenthic form (Berkman et al., 2004, p. 1845). Although these bivalves are believed to have occupied water depths not greater than 100 m (Jonkers, 1998a; Jonkers et al., 2002), sometimes they occur as transported fragmentary specimens in strata that may have been deposited at greater water depths (Jonkers et al., 2002, p. 586).

Austrochlamys is a significant indicator of palaeoenvironment for the Antarctic (Berkman et al., 2004). Modern Austrochlamys natans occur in the high energy sub-littoral and littoral zones of southern Chile and Argentina, as far south as Bahia Orange (Dijkstra and Köhler, 2008). Modern sea surface temperatures in southernmost South America range between about 5 to $10^{\circ} \mathrm{C}$ (NOAA monthly global SST plot archive at: http://www.emc.ncep.noaa.gov/research/cmb/sst_analysis/). As well as living at shallow depths Austrochlamys is recovered from greater depths, and for example the holotype of A. natans was recovered from $125 \mathrm{~m}$ in the Magellan Strait (see Dijkstra and Marshall, 2008). Seawater temperatures in southernmost South America (between 52 to $56^{\circ} \mathrm{S}$ ) at depth $125 \mathrm{~m}$ range between about 4 to $8^{\circ} \mathrm{C}$ annually, and at $500 \mathrm{~m}$ are between 4 to $6^{\circ} \mathrm{C}$ (NODC 
133 World Ocean Atlas, Monthly Mean one degree sea temperatures at:

134 http://apdrc.soest.hawaii.edu/las/servlets/dataset). Berkman et al. (2004) have argued that the 135 presence of Austrochlamys in Antarctic fossil assemblages suggests similar conditions to modern southernmost South America, and in particular, much reduced sea ice extent. Jonkers (1998a) also suggested a sea ice free environment for the Cockburn Island Formation, based on the presence of barnacles in his littoral facies and the absence of ice-rafted debris. Opal depositional rates, which 139 are linked to biological productivity, are conspicuously enhanced in the Early Pliocene, between 5.2 and 3.1 Ma, signifying much-reduced sea ice cover (Hillenbrand and Fütterer, 2002; Pudsey, 2002).

141 Although microfossil assemblages found in the ODP Leg 178 drift sediments show no evidence of significantly warmer surface water temperatures than today (Hillenbrand and Fütterer, 2002), Hepp et al. (2006) have suggested open ocean conditions in the warm Early Pliocene, even during glacials. In addition, diatom evidence from ODP site 1165 (in the Southern Ocean at $64.384^{\circ} \mathrm{S}$ ) reported by Whitehead and Bohaty (2003) gives mean annual temperatures at $4^{\circ} \mathrm{C}$, and the absence of ice-rafted debris in the Cockburn Island Formation (Jonkers, 1998a) also suggests warmer conditions than present.

Modern coastal environments of James Ross Island and other Antarctic regions, where seasonal sea ice is prevalent, are characterised by the slow-growing, thin-shelled scallop Adamussium colbecki (Berkman et al., 2004). This bivalve is thought to have originated in deeper water and to have migrated on to the shelf as conditions cooled during the Late Pliocene. Adamussium colbecki lives below sea ice, in conditions that mimic the deep ocean. It effectively replaced Austrochlamys as the dominant scallop, which retreated across the Southern Ocean to

154 South America (Berkman et al., 2004). Thus, Austrochlamys may provide a proxy of reduced sea 155 ice conditions and more agitated coastal waters around James Ross and Cockburn islands during the 156 Pliocene, a hypothesis that we will test in this paper by examining the growth-increment pattern and geochemical signature of fossil shells. 
159

160

161

162

163

164

165

166

167

168

169

170

171

172

173

174

175

176

177

178

179

180

\section{Methodology: analysis of bivalve material}

Our methodology to understand the growth and habitat of fossil Austrochlamys in the Cockburn

Island Formation uses three lines of evidence: oxygen isotopes to determine seasonality and the approximate temperature of the water in which the bivalves were living; carbon isotopes to determine metabolic rates and food supply during growth; and growth increments to assess the pattern of growth. Relating these different data sources is a means of providing a detailed picture of the environmental setting of Austrochlamys in the late Neogene coastal waters of the Antarctic.

\subsection{Geochemical analyses}

Only well-preserved fossil material has been analysed. Neogene shells of Austrochlamys from the Antarctic Peninsula that we interpret as being pristine show no variation in composition that is detectable under Scanning Electron Microscopy (with EDX analysis). With the exception of a few specimens, the shell lamellae have no visible cement overgrowths or recrystallisation. The calcitic shell lamellae (confirmed by XRD analysis of 3 shell fragments) are non-luminescent to weakly luminescent under cathodoluminescence, indicating no diagenetic cements are present. One specimen has a diagenetic cement overgrowth on the external surface of the valve as bladed calcite crystals, which are strongly luminescent (Fig. 4), and this specimen has been excluded from the isotopic analysis. Many shells have a fine layer of carbonate-cemented clay material adhering to the outer surface of the shell. Before drilling for geochemical analysis, this extraneous material was removed by gentle scrubbing and immersion of the shell in a bath of $5 \% \mathrm{HCl}$ followed by washing with de-ionised water. After this treatment the shells looked pristine with the majority of the sediment removed and the growth increments clearly showing. The growth increments of Austrochlamys are large and easy to drill and it is possible to obtain sufficient material from each, whilst avoiding remaining adherent sediment. Shells representing several years of growth (e.g. DJ.851.159, DJ.851.160 and DJ.853.1) were selected for analysis. Some 250 growth increments from three shells have been sampled for calcite and analysed for stable carbon and oxygen isotopes 
185 (Figs 3, 6). Approximately 30-100 micrograms of carbonate have been used for each isotope

analysis using a GV IsoPrime mass spectrometer plus Multiprep device. Isotope values $\left(\delta^{13} \mathrm{C}, \delta^{18} \mathrm{O}\right)$ are reported as per mil (\%o) deviations of the isotopic ratios $\left({ }^{13} \mathrm{C} /{ }^{12} \mathrm{C},{ }^{18} \mathrm{O} /{ }^{16} \mathrm{O}\right)$ calculated to the VPDB scale using a within-run laboratory standard calibrated against NBS standards. Analytical reproducibility of the standard calcite $(\mathrm{KCM})$ run with these samples was $0.02 \%$ for $\delta^{13} \mathrm{C}$ and $0.04 \%$ for $\delta^{18} \mathrm{O}$. Values for oxygen isotopes have been converted to sea palaeotemperatures using the equation of $\mathrm{O}^{\prime}$ Neil et al. $(1969), \mathrm{T}=16.9-4.38\left(\delta^{18} \mathrm{O}_{\mathrm{c}}-\delta^{18} \mathrm{O}_{\mathrm{sw}}\right)+0.10\left(\delta^{18} \mathrm{O}_{\mathrm{c}}-\delta^{18} \mathrm{O}_{\mathrm{sw}}\right)^{2} . \mathrm{A}$. Johnson et al. (2000) have demonstrated good calibration between actual sea temperatures and reconstructed sea temperatures using this equation applied to North Sea modern and sub-fossil Aequipecten. For comparison we have also calculated palaeotemperatures using a modified form of the Craig (1965) equation given in Leng and Marshall (2004), $\mathrm{T}=16-4.14\left(\delta^{18} \mathrm{O}_{\mathrm{c}}-\delta^{18} \mathrm{O}_{\mathrm{sw}}\right)+$ $0.13\left(\delta^{18} \mathrm{O}_{\mathrm{c}}-\delta^{18} \mathrm{O}_{\mathrm{sw}}\right)^{2}$ : typically this makes palaeotemperature estimates warmer by about 0.5 to $0.8^{\circ} \mathrm{C}$ (see Table 1$)$.

\subsection{Assessing seawater isotopic composition}

Implicit in calculations of palaeotemperature from the $\delta^{18} \mathrm{O}$ of Austrochlamys calcite is an assessment of the isotopic composition of the seawater $\left(\delta^{18} \mathrm{O}_{\mathrm{sw}}\right)$ in which the bivalves were living. Surface seawater $\delta^{18} \mathrm{O}$ in the Weddell Sea today is between 0 and $-0.5 \%$ (Schmidt et al., 1999). Mackensen (2002) gives a mean value of $-0.37 \%$ for Antarctic Surface Water in the southern Weddell Sea. Oceanographic conditions in the Weddell Sea have been summarized by Whitehouse et al. (1996), who showed summer to winter temperature variation between +1.99 and $-0.10^{\circ} \mathrm{C}$, with salinity greater in winter time (33.87 to $34.05 \mathrm{psu}$ ) than in summer (33.81 to $33.86 \mathrm{psu}$ ). The flux of isotopically light glacial meltwater into the northern Weddell Sea around James Ross Island during the summer months affects the $\delta^{18} \mathrm{O}$ of surface water. Although there are no detailed studies of meltwater flux around James Ross Island, these effects are well constrained for surface water on 
211 setting of Marguerite Bay is different from that of the Weddell Sea in that $\delta^{18} \mathrm{O}_{\mathrm{sw}}$ values in the 212 western peninsula region are lower for surface waters (between -0.5 to $-1 \%$; see Schmidt et al., 213 1999). However, the north end of Marguerite Bay is covered by winter sea ice for several months, 214 so that it provides a useful comparison for seasonal fluxes of sea ice and glacial meltwater into the 215 modern James Ross Island area, where sea ice also forms during the winter months. In Marguerite 216 Bay as much as $5 \%$ of the near-surface ocean is glacial meltwater: sea ice-melt accounts for a much 217 smaller percentage ( $c a 1 \%$ ). The effects of seasonal sea ice-melt on the $\delta^{18} \mathrm{O}_{\mathrm{sw}}$ are minimal 218 (Meredith et al., 2008, p. 314) but those of glacial ice-melt are much more significant as high 219 latitude ice has very low $\delta^{18} \mathrm{O}$ (Mackensen, 2002; Meredith et al., 2008). In Marguerite Bay surface waters are isotopically lightest during the summer months, with values as low as $-0.9 \%$ (compared with higher values of $-0.1 \%$ for deeper water below $300 \mathrm{~m}$ ). During winter months the $\delta^{18} \mathrm{O}$ of surface waters is about $-0.5 \%$, still much lower than deeper waters and indicating that significant quantities of meteoric water remain in the upper water column throughout the year. Our estimates of palaeotemperature from Austrochlamys have assumed an initial surface $\delta^{18} \mathrm{O}_{\text {sw }}$ value of $-0.2 \%$. This is a mean value sourced from a climate model study of the Early Pliocene (Lunt et al., 2008) and is similar to modern surface conditions in the Weddell Sea (Schmidt et al., 1999; Mackensen, 2002). For calculations of $\delta^{18} \mathrm{O}_{\mathrm{sw}}$ from the model see Appendix 1. There is considerable evidence for the persistence of an Antarctic Peninsula Ice Sheet even during warm phases of the late Neogene (Smellie et al., 2009; J. Johnson et al., 2009; Nelson et al., 2009), though sea ice cover in this region may have been much more limited (Berkman et al., 2004). Thus, fluxes of meltwater such as those into Marguerite Bay may have characterized the northern Weddell Sea region during warm interval summers, and may have kept surface waters 233 isotopically light throughout the year, with $\delta^{18} \mathrm{O}$ values lowest during the summer. For this reason, we have also calculated palaeotemperatures using higher and lower values of $\delta^{18} \mathrm{O}_{\text {sw }}(0$ to $-0.4 \%$ ) to reflect seasonal (winter-summer) variation (see Table 1). 


\subsection{Growth increment analysis}

Austrochlamys grows by a series of increments that are visible on the shell surface (Fig. 3). These increments result from the advance of the mantle over the ventral margin to effect extension of extrapallial fluid and precipitation of calcite to the shell edge. In scallops, as in other bivalves, large-scale mantle advance and shell-size increase is dependent on the environmental conditions which facilitate cell division and growth. However, under such conditions, shell extension is fairly regularly interrupted for short periods through retraction of the mantle edge, resulting in an incremental pattern of shell growth which is clearly marked by commarginal ridges on the external surface (Clark, 1974, 2005). The individual (microgrowth) increments may be over $1 \mathrm{~mm}$ in width in Austrochlamys (Fig. 5), which is exceptionally large amongst scallops (cf. Clark, 2005; Owen et al., 2002b; A. Johnson et al., 2009). Overall periods of growth may be succeeded by sudden and sharp reductions in calcite precipitation, and the shell is therefore marked by a distinct band known as a 'growth line'. These lines may represent suspension of growth associated with seasonal temperature extremes, wave action, reproduction (Dame, 1996, p. 58) or disturbance (e.g. Adam, 1990). In Austrochlamys from the Cockburn Island Formation growth lines are developed on many shells with varying degrees of prominence (Fig. 3).

To measure growth increments precisely, scaled photographic images of Austrochlamys were imported into the software Panopea (@ Peinl and Schöne, 2004). This enables point-to-point measurements of growth increment widths and reference features, and outputs a precise width of these structures. The factors behind the rate of growth of Austrochlamys cannot be differentiated by growth increments alone (see Jones and Quitmyer, 1996), but coupled to $\delta^{13} \mathrm{C}$ and $\delta^{18} \mathrm{O}$ profiles (see A. Johnson et al., 2000, 2009) it is possible to make inferences about control mechanisms such as food supply and water temperature.

\section{Results and interpretation}


263 The three shells we have analysed for stable isotopes collectively record about seven summer-

264 winter cycles of growth (Fig. 6), with an overall reconstructed temperature range from -1 to $+3.5^{\circ} \mathrm{C}$ 265 (using the O'Neil et al., 1969 equation), or slightly higher minimum and lower maximum 266 temperatures if higher winter and lower summer $\delta^{18} \mathrm{O}_{\mathrm{sw}}$ values are used (Table 1). We do not 267 suggest that this represents the entire range of climate for the Cockburn Island Formation, but it 268 does provide the first quantifiable evidence of sea temperature seasonality for about seven years in 269 this region from the late Neogene. The two shells from locality DJ.851 show similar temperature 270 profiles, while that from locality DJ.853 shows the warmest summer values (Fig. 6, Table 1). These 271 two bivalve-bearing localities are separated by about $300 \mathrm{~m}$ along a north-south transect on the east 272 side of the island (Fig. 2) and while the bivalves are from the same substratum, they may represent 273 molluscs living 100s of years apart.

Isotope analysis of shell DJ.851.159 shows a signal of seasonality in water temperature over 275 three cycles of summer-winter growth (Fig. 6). During this interval (using an annual mean $\delta^{18} \mathrm{O}_{\text {sw }}$ of $-0.2 \%$ and the O'Neil et al., 1969 equation), sea temperatures between -1.1 and $+2.5^{\circ} \mathrm{C}$ are

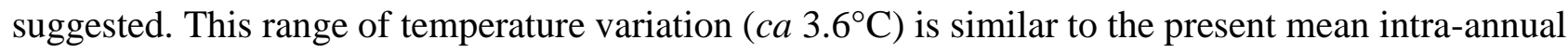
range in surface waters of the Weddell Sea (see Whitehouse et al., 1996). It is also similar to the seasonal temperature variation at the sea surface predicted by an Early Pliocene climate model, 280 giving values of $-1.69^{\circ} \mathrm{C}$ for winter (July) and $+3.08^{\circ} \mathrm{C}$ for summer (February) at depth $0-5 \mathrm{~m}$ (Lunt et al., 2008). At depth $(95-113 \mathrm{~m})$ seasonality from the model is just -0.69 to $-0.52^{\circ} \mathrm{C}$. This supports the notion that the Austrochlamys of the Cockburn Island Formation were living at shallow depth, recording much of (or the entire) surface seasonality, and were well above the maximum depth of $100 \mathrm{~m}$ speculated on by Jonkers et al. (1998a, 2002).

The use of a single mean annual value for $\delta^{18} \mathrm{O}_{\mathrm{sw}}$ in our calculations shown in Figure 6 may be unjustified (and lead to over- or underestimates of palaeotemperature) in that it assumes no large change in glacial meltwater flux to this region of the northern Weddell Sea between summer and winter. Calculating sea temperatures for shell DJ.851.159 using a winter value of $0 \%$ for $\delta^{18} \mathrm{O}_{\text {sw }}$ 
gives a minimum water temperature of $-0.4^{\circ} \mathrm{C}$, close to that recorded today. Using a summer value of $-0.4 \%$ for $\delta^{18} \mathrm{O}_{\text {sw }}$ gives a maximum temperature of about $2^{\circ} \mathrm{C}$ (Table 1). This seasonal range in $\delta^{18} \mathrm{O}_{\mathrm{sw}}$ is justified by modern data from Marguerite Bay (see Meredith et al., 2008 and above). Forty analyses from shell DJ.851.160 produce estimated sea temperatures similar to those of shell DJ.851.159, with a minimum just below $0^{\circ} \mathrm{C}$ and a maximum of $1.8^{\circ} \mathrm{C}$ (for $\delta^{18} \mathrm{O}_{\mathrm{sw}}=-0.2 \%$, see Fig. 6, see also Table 1). In contrast, shell DJ.853.1, which also records about three cycles of summer-winter growth ( $\mathrm{ca} 100$ increments drilled), provides sea temperatures between 0.5 and $3.5^{\circ} \mathrm{C}$ (for $\delta^{18} \mathrm{O}_{\mathrm{sw}}=-0.2 \%$, Fig. 6). Given that these shells are from two different localities, the latter hints that a very detailed record of changing regional climate may be stored in these fossils.

Modern temperature beneath the sea ice during winter months in the Weddell Sea is close to $0^{\circ} \mathrm{C}$ (Whitehouse et al., 1996; cf. with similar sea temperatures in Marguerite Bay reported by Meredith et al., 2008, p. 312), suggesting that our estimates of winter temperature in shells from locality DJ.851 may be too cool for the Early Pliocene. Although the overall degree of seasonal sea temperature change appears similar to present (Table 1), we cannot be sure that our reconstructed temperatures reflect absolute values. However, given a winter temperature of $-1.1^{\circ} \mathrm{C}$ from bivalve DJ.851.159, they must represent near minimum values. Recalculating palaeotemperatures using the modified form of the 'Craig (1965)' equation (see Table 1) gives a slightly elevated minimum temperature of $-0.3^{\circ} \mathrm{C}$ for shell DJ.851.159, close to the modern minimum values recorded by Whitehouse et al. (1996).

As well as the problem of assessing initial $\delta^{18} \mathrm{O}_{\text {sw }}$ some bivalves are known to exhibit vital effects. Thus, experimental work on Pecten maximus shows deviations of shell $\delta^{18} \mathrm{O}$ from equilibrium of $+0.6 \%$, equivalent to a temperature interpretation $2-3^{\circ} \mathrm{C}$ colder than actual (Owen et al., 2002a). With our available data we cannot assess whether vital effects have influenced the $\delta^{18} \mathrm{O}$ of Austrochlamys calcite, but it is feasible that our minimum and maximum estimates of sea temperature are colder than actual, and that sea temperatures were above zero throughout the year at the time the Cockburn Island Formation was being deposited. This is suggested by sea temperature 
315 values from the shell at locality DJ.853 that show a minimum above $0^{\circ} \mathrm{C}$ (Fig. 6, Table 1), and by 316 our growth increment data (see below).

\subsection{Carbon isotopes and planktonic productivity}

319 The $\delta^{13} \mathrm{C}$ signature of bivalves is influenced by the isotopic composition of the dissolved inorganic 320 carbon (DIC) in seawater, its major controls being local phytoplankton productivity (removing ${ }^{12} \mathrm{C}$ ),

321 local respiration (returning ${ }^{12} \mathrm{C}$ ) and influxes of isotopically more negative deep ocean water or 322 freshwater (Krantz et al., 1987). Thus, bivalves living close to upwelling zones can exhibit marked 323 changes in $\delta^{13} \mathrm{C}$ (Jones and Allmon, 1996) whereas those living away from such zones may exhibit 324 a much smaller degree of variation, less than $1 \%$ (A. Johnson et al., 2000, 2009). The $\delta^{13} \mathrm{C}$ may 325 also reflect a kinetic effect. This results in a depletion of both ${ }^{18} \mathrm{O}$ and ${ }^{13} \mathrm{C}$ in carbonates 326 (McConnaughey et al., 1997; Owen et al., 2002a). In contrast, metabolic (respiration) effects will be 327 reflected in depletions in shell $\delta^{13} \mathrm{C}$ (McConnaughey and Gillikin, 2008) which are not 328 accompanied by simultaneous changes in shell $\delta^{18} \mathrm{O}$. Thus, the two mechanisms can be 329 differentiated in isotopic profiles of bivalves.

The carbon isotope signature of $A$. anderssoni suggests both metabolic and oceanographic 331 controls, but not kinetic effects. Carbon isotope values are lowest through the first annual cycle of 332 temperature variation recorded in shell DJ.851.159 ( $\mathrm{ca}$ 1.4\%o), perhaps related to high metabolic 333 rate in a young specimen. The carbon signature is a little higher through the second cycle of 334 temperature variation recorded in shell DJ.851.159 ( $\mathrm{ca}$ 1.7\% ), and then is variable into the third 335 cycle (from $\mathrm{ca} 1.2$ to nearly $2 \%$ ). However, the two peaks of highest carbon values (at about $2 \%$ ) 336 correlate with summer temperature maxima determined from analysis of $\delta^{18} \mathrm{O}$ (Fig. 6), and suggest 337 a phytoplankton control, influenced by a summer bloom. There are no areas of the shell DJ.851.159 338 profile where oxygen and carbon show depletion in tandem, and we interpret this as being evidence 339 of minimal or no kinetic effects. A very similar pattern of highest $\delta^{13} \mathrm{C}$ (about $2 \%$ ) associated with 340 summer temperature is also preserved in shell DJ.851.160 (Fig. 6). Peak highest values of $\delta^{13} \mathrm{C}$ also 
341 coincide with warmest estimated sea temperatures in bivalve DJ.853.1. Here though, peak highest

$342 \delta^{13} \mathrm{C}$ values (of 2.4\%o) are greater than in the two bivalves from locality DJ.851, suggesting that 343 increased water column productivity might have been influenced by the warmer overall 344 temperatures apparently experienced by bivalve DJ.853.1.

345 Conceivably, more upwelling of deep ocean water in winter-time could produce the 346 characteristic low $\delta^{13} \mathrm{C}$ patterns that correlate with the highest $\delta^{18} \mathrm{O}$ in the three shells analysed (Fig. 347 6). Differences in wind strength between summer (weaker) and winter (stronger) could account for 348 this, but these differences could not have had an effect if the sea was ice-covered in winter.

\subsection{Growth increments and the availability of benthic food}

351 All of the bivalves measured show patterns in growth involving clusters of broader and narrower 352 increments (Fig. 5). The initial (umbonal) region of each shell bears increments which are too 353 narrow or ill-defined to be measured (Fig. 3). This is typically over the first 2-3 cm of well354 preserved shells. Thus, we have been unable to assess growth patterns for the earliest stages of 355 development in Austrochlamys and it should be noted that the graphs do not represent the same 356 growth increment interval between bivalves (see Fig. 3 for position of growth measured on each 357 shell). For those increments that can be measured, there is a wide range of variation in width both 358 within and between shells, varying from $0.09 \mathrm{~mm}$ (DJ.852.1) to $\mathrm{ca} 1.7 \mathrm{~mm}$ (DJ.851.3). Some 359 specimens clearly have broader growth increments overall: thus, $5 \mathrm{~cm}$ of shell growth can be 360 achieved over 60 (e.g. DJ.851.3), 76 (DJ.851.80) or 93 increments (DJ.851.159). The number of 361 increments between a peak and a trough in the growth of Austrochlamys varies from about 3 to 14, 362 with no discernible increase in frequency from younger to older specimens (Fig. 5). 363 Notwithstanding the growth lines that represent probable growth breaks, analysis of growth 364 cumulatively suggests that while Austrochlamys is growing, growth rate remains similar, with no 365 significant reduction during colder periods (see Fig. 6). 
The annual cycles in environmental variables (e.g. sea temperature and phytoplankton

367 productivity) determined from stable oxygen and carbon isotope analyses correspond to growth 368 intervals involving from 24 to 38 increments on shell DJ.851.159, with winter troughs at increments 36919,57 and beyond 81 (and summer highs at increments 1, 39 and 75 respectively). The winter370 summer signal from the isotopes is clearly independent of the growth variation exhibited by the 371 increments, which have a much higher frequency of change (Fig. 6) and were likely controlled by 372 other factors. In addition, the seasonal temperature signal does not appear to bear any close 373 relationship to the distinctive growth lines of shell DJ.851.159, at least one of which appears to be associated with marginal shell damage (see Figs 3,6) and therefore perhaps disturbance. Shell DJ.851.160, from the same locality as DJ.851.159, confirms this pattern, with growth increment variation of similar degree in both summer and winter, and a growth line in the part of the shell drilled for stable isotopes which is synchronous with rising temperatures, probably towards the end of a winter cycle (Fig. 6).

In contrast shell DJ.853.1, from the northern-most pectinid-bearing locality on Cockburn Island (Fig. 2) shows a different pattern of growth to those shells from locality DJ.851. In this shell two growth lines do equate to intervals of temperature lows (Fig. 6), though not to the final low temperature interval (beyond increment 90). From increment 1 to 59 there is no apparent summer383 winter variation in overall growth rate when the bivalves are growing, with peaks and troughs in increment width occurring with a higher frequency than the peaks and troughs in temperature variation (fig. 6). The first weak growth line appears to come towards the end of a winter cycle, and is associated with a temperature low. But this growth break appears to have been of short duration 387 as there is a substantial interval of winter prior to this (Fig. 6). It occurs in that part of the shell 388 where the $\delta^{13} \mathrm{C}$ signal indicates a rapid increase in water column productivity, and therefore the 389 growth line probably formed at, or just prior to the beginning of spring-summer. The second growth 390 line, beginning at about increment 58, is stronger and corresponds to a temperature low. Here there 391 is clear evidence for a slowing of growth (from increment size measurements, Fig. 6), and this part 
392 of the shell is also associated with a rapid change to lower $\delta^{13} \mathrm{C}$ that may record the onset of winter.

393 The isotope record is missing through about 5 to 6 increments as these were too narrow to drill, and 394 so the winter temperature minimum has not been determined. The increments immediately 395 following the growth line show rapid temperature rise into summer (Fig. 6). Nevertheless, the 396 temperature low associated with this growth line (and apparent growth cessation) was well above 397 zero at the time growth slowed (Fig. 6), and is in line with winter temperature values elsewhere in 398 this shell where growth continued. We therefore suggest that this growth break might be associated 399 with shell disturbance, rather than with growth cessation from low temperature. Shell DJ.853.1 400 records a second season of summer growth with a maximum estimated temperature of $3.5^{\circ} \mathrm{C}$ at 401 increment 72 , and a final period of presumed winter growth with temperatures about $1.5^{\circ} \mathrm{C}$ beyond 402 increment 88 (Fig. 6). There is no distinctive growth line associated with the beginning of this last 403 interval of 'cooler' temperatures, and increment analysis indicates that growth continued at a 404 similar pace irrespective of whether temperatures were 'warm' or 'cool' (Fig. 6). Conventional wisdom interprets the growth patterns of bivalves in terms of summer to 406 winter variation, but Jones and Quitmyer (1996) have demonstrated convincingly that there may be 407 a decoupling between growth rate and temperature in bivalves. The growth-increment patterns in 408 the shells analysed for stable isotopes from the Cockburn Island Formation (Figs 3, 6) are closely 409 comparable to those of Holocene Aequipecten from the North Sea (A. Johnson et al., 2009) - that is, 410 there is no seasonal pattern that can be tied with the palaeotemperature profile reconstructed from 411 stable oxygen isotope evidence. Neither is there any correspondence to the pattern of planktonic 412 productivity inferred from carbon isotope evidence. In natural populations of the scallop 413 Aequipecten growth is probably tied with benthic food supply, particularly with the availability of 414 detrital organic material. This increases during periods of water column agitation. Growth in the 415 infaunal bivalve Arctica appears to be under a similar control (Schöne et al., 2003, 2005; Witbaard, 416 1996) and the correlation between increment size in Pliocene Flabellipecten steamsi from the Gulf 417 of California and tidal patterns in this area (Clark, 2005) is also accountable to re-suspension and 
418 advection of detrital food by tidal currents. In the Weddell Sea, present winter sea ice-cover

419 suppresses movement in the water column during the winter months. Therefore, if sea ice was extensive during the winter months of the Early Pliocene, this would have resulted in reduced 421 agitation of the water column, reduced food supply, and a clear seasonality in growth for $A$. anderssoni. Moreover, there should be less short-term variation in winter than in summer (when the water column would be more agitated), but this is not the case. The growth increment data from $A$. anderssoni is consistent with the proposal of Berkman et al. (2004) that there was reduced (or no) sea ice in Early Pliocene coastal marine settings occupied by Austrochlamys. The data also imply that Austrochlamys has retreated from the Antarctic as the extent of sea ice grew, probably during cooling in the Late Pliocene to Pleistocene. These Antarctic coastal zones today are colonised by the slow-growing Adamussium colbecki, a bivalve that originated in deeper waters that are mimicked by living below sea ice (see Berkman et al., 2004).

\section{Marine seasonality and environment on the Antarctic Peninsula during the Early Pliocene}

Our data provide a signal of seasonality during warm interglacial phases of Antarctic climate in the late Neogene and allow testing of models of sea ice extent during the Early Pliocene. Growth increment analysis coupled with stable isotope data indicates that sea temperature was not the major influence on growth for $A$. anderssoni. Instead, growth appears to have continued throughout much of the year (even during the coldest parts of winter as recorded in our shells) with a high frequency fluctuation that probably reflects periodic agitation of the water column and enhanced benthic food supply from organic detritus. Such an interpretation differs from the suggestion of Jonkers et al.

439 (2002, p. 587) that the occurrence of A. anderssoni in both the Hobbs Glacier (glacial) and 440 Cockburn Island (glacimarine/interglacial) formations indicates its wide environmental tolerance, 441 and that it should therefore not be used solely as an indicator of interglacial (= present-like conditions). Our evidence also suggests that Austrochlamys favoured waters that were sea ice-free, 
444 end of an interglacial. Ice-proximal glaciomarine debris flows on James Ross Island incorporated 445 well-preserved bivalves and bryozoans, suggesting that ice expansion occurred under warm 446 conditions during the Pliocene, probably towards glacial inception (Nelson et al., 2009). The 447 presence of bivalves in close proximity to the palaeo-coastline supports the hypothesis of a lack of 448 sea ice, despite the presence of advancing terrestrial-based ice on James Ross Island and the 449 Antarctic Peninsula.

The range of temperatures recorded by the bivalves is similar to the mean annual sea surface 451 temperature range in this region at present (see Table 1). Using the O'Neil et al. (1969) equation, 452 and assuming no vital effects and that our estimates of $\delta^{18} \mathrm{O}_{\mathrm{sw}}$ approximate reality, the shells that we 453 have analysed show minimum and maximum temperatures to have been between about -1.1 and $454+2.5^{\circ} \mathrm{C}$ for the bivalves of locality DJ.851, and temperatures between 0.5 and $3.5^{\circ} \mathrm{C}$ for locality 455 DJ.853: the temperature range is slightly warmer if we use the modified form of the Craig (1965) equation (see Table 1) with values of -0.3 to $2.8^{\circ} \mathrm{C}$ for DJ.851 and 1.1 to $3.7^{\circ} \mathrm{C}$ for DJ.853. Our 457 growth increment data, coupled with supporting palaeotemperature information, support: the 458 interpretation of the Cockburn Island Formation as an interglacial marine deposit; the notion of 459 reduced sea ice in the Antarctic during the Pliocene (e.g. Whitehead et al., 2005); and the 460 hypothesis of Berkman et al. (2004) that Austrochlamys retreated from the Antarctic as sea ice 461 expanded, this transition occurring during climate cooling in the Late Pliocene. Our bivalve data 462 question climate model predictions of extensive sea ice in the Weddell Sea during the Early 463 Pliocene.

\section{Further work}

466 Our work has demonstrated the potential value of Austrochlamys for testing hypotheses of 467 seasonality and sea ice extent for pre-Quaternary time slices in the Antarctic. As both the Hobbs 468 Glacier and Cockburn Island formations bear rich bivalve material over a wider stratigraphical 469 range than we have analysed here, there is great scope for developing a highly resolved proxy for 
marine palaeoseasonality at these latitudes. Together with the largely unstudied cheilostome bryozoan faunas in the JRIVG - themselves a group of fossils which are excellent proxies for mean annual range of temperature (see Knowles et al., 2009) - a highly resolved record of palaeoclimate through the Late Miocene and Pliocene of the Antarctic Peninsula region may be obtainable.

\section{Acknowledgments}

The growth increment analysis of Austrochlamys was undertaken by Daniel Jarram as part of his final year Masters project at the University of Leicester. This work contributes to the British Antarctic Survey's GEACEP Programme (ISODYN Project - Ice House Earth: Stability or Dynamism), to the British Geological Survey's deep time palaeoclimate project, and to the SCAR ACE Programme (Antarctic Climate Evolution). We acknowledge support from the NERC Isotope Geosciences Facilities Steering Committee (grant IP/936/1106). We thank Captain Bob Tarrant and the officers and crew of HMS Endurance for their assistance during the 2006-2007 field season, Mark Laidlaw for field assistance and Paul Brickle (Falkland Island Fisheries) for supplying sub-fossil material of Austrochlamys from the Falkland Islands. Alistair Crame (BAS) is thanked for permission to analyse the bivalve material geochemically. Colin Cunningham and Rob Wilson (Leicester) made thin sections and helped with SEM photomicrography, respectively. The late Tim Brewer ran analyses of shell geochemistry for us and advised on shell preservation. Cheryl Haidon undertook the XRD analysis of shells. We are especially grateful to Hilary Sloane (NIGL) for assistance with the isotope analysis, to Arne Ghys (Belgium) for supplying comparative modern Austrochlamys material from Tierra del Fuego, and to Harry Dowsett (USGS) and Daniel Lunt (Bristol) for their constructive reviews. BRS acknowledges financial support by a DFG (SCHO793/4). This is Geocycles publication number X.

\section{References}

Adam, M.E. 1990. Shell growth in some Nile bivalves. Journal of Molluscan Studies, 56, 301-308.

Berkman, P.A., Cattaneo-Vietti, R., Chiantore, M., Howard-Williams, C. 2004. Polar emergence and the influence of increased sea-ice extent on the Cenozoic biogeography of pectinid molluscs in Antarctic coastal areas. Deep Sea Research Part 2, 51, 1839-1855.

Bigg, G. R., Rohling, E.J. 2000. An oxygen isotope data set for marine waters, Journal of Geophysical Research, 105, 8527-8535

Clark II, G.R. 1974. Calcification on an unstable substrate: marginal growth in the mollusk Pecen 
diegensis. Science, 183, 968-970.

500 Clark II, G.R. 2005. Daily growth lines in some living Pectens (Mollusca: Bivalvia) and some applications in a fossil relative: Time and tide will tell. Palaeogeography, Palaeoclimatology, Palaeoecology, 228, 26-42.

Craig, H. 1965. The measurement of oxygen isotope palaeotemperatures. In: Tongiorgi, E. (Ed.), Stable Isotopes in Oceanographic Studies and Palaeotemperatures. Pisa, Consiglio Nazionale delle Ricerche Laboratorio di Geologia Nucleare, pp. 161-182.

Dame, R.F. 1996. Ecology of marine bivalves: an ecosystem approach. CRC Press: Boca Raton, Florida. 254 pp.

Dijkstra, H.H., Köhler, F. 2008. An annotated catalogue of Recent Pectinoidea (Mollusca, Pectinidae and Propeamussiidae) type material in the Museum of Natural History, Humboldt University, Berlin. Zoosystematics and Evolution, 84, 31-44.

Dijkstra, H.H., Marshall, B.A. 2008. The Recent Pectinoidea of the New Zealand region (Mollusca: Bivalvia: Propeamussiidae, Pectinidae and Spondylidae). Molluscan Research, 28, 1-88.

Dowsett, H.M. 2007. The PRISM palaeoclimate reconstruction and Pliocene sea-surface temperature. In: Williams, M., Haywood, A.M., Gregory, F.J., Schmidt, D.N. (eds.) DeepTime Perspectives on Climate Change: Marrying the Signal from Computer Models and Biological Proxies. The Micropalaeontological Society, Special Publications, The Geological Society, London, pp. 459-480.

Epstein, S., Buchsbaum, R., Lowenstam, H.A., Urey, H.C. 1953. Revised carbonate water isotopic temperature scale. Geological Society of America Bulletin, 64, 1315-1326.

Hambrey, M.J., Smellie, J.L., Nelson, A.E., Johnson, J.S. 2008. Late Cenozoic glacier-volcano interaction on James Ross Island and adjacent areas, Antarctic Peninsula region. Geological Society of America Bulletin, doi: 10.1130/B26242.1.

Haywood, A.M., Valdes, P.J., Peck, V.L. 2007. A permanent El Nino-like state during the Pliocene? Paleoceanography, 22 (1), doi:10.1029/2006PA001323 
Haywood, A.M., Valdes, P.J., Hill, D.J., Williams, M. 2007. The mid-Pliocene warm period: A test-bed for integrating data and models. In: Williams, M., Haywood, A.M., Gregory, F.J., Schmidt, D.N (eds) Deep time perspectives on climate change: marrying the signal from computer models and biological proxies. The Micropalaeontological Society, Special Publications. The Geological Society, London, 443-457.

Haywood, A.M., Dowsett, H.J., Valdes, P.J., Lunt, D.J., Francis, J.E., Sellwood, B. 2009. Pliocene climate, processes and problems. Philosophical Transactions of the Royal Society, Series A, 367, 3-17.

Hepp, D.A., Mörz, T., Grützner, J. 2006. Pliocene glacial cyclicity in a deep-sea sediment drift (Antarctic Peninsula Pacific Margin). Palaeogeography, Palaeoclimatology, Palaeoecology, 231, 181-198.

Hillenbrand, C-D., Fütterer, D.K. 2002. Neogene to Quaternary deposition of opal on the continental rise west of the Antarctic Peninsula, ODP Leg 178, Sites 1095, 1096, and 1101. In: Barker, P.F., Camerlenghi, A., Acton, G.D., Ramsay, A.T.S. (eds) Proceedings of the Ocean Drilling Programme, Scientific Results, 178. Texas A and M University, College Station, Texas, $1-40$ (CD-ROM).

Jansen, E.. Overpeck, J., Briffa, K.R., Duplessy, J.-C., Joos, F., Masson-Delmotte, V., Olago, D., Otto-Bliesner, B., Peltier, W.R., Rahmstorf, S., Ramesh, R., Raynaud, D., Rind, D., Solomina, O., Villalba, R., Zhang, D. 2007. Palaeoclimate. In: Climate Change 2007: The Physical Science Basis. Contribution of Working Group I to the Fourth Assessment Report of the Intergovernmental Panel on Climate Change, Cambridge University Press, Cambridge, United Kingdom and New York, NY, USA.

Johnson, A.L.A., Hickson, J.A., Swan, J., Brown, M.R., Heaton, T.H.E., Chenery, S., Balson, P.S. 2000. The Queen Scallop Aequipecten opercularis: a new source of information on late Cenozoic marine environments in Europe. In: Harper, E.M., Taylor, J.D., Crame, J.A. (eds) The 
Evolutionary Biology of the Bivalvia. pp. 425-439. Geological Society of London, Special Publications 177.

Johnson, A.L.A., Hickson, J.A., Bird, A., Schoene, B.R., Balson, P.S., Heaton, T.H.E., Williams, M. 2009. Bivalve sclerochronology and the mid-Pliocene (c. 3.5 Ma) climate of the Southern North Sea Basin. Palaeogeography, Palaeoclimatology, Palaeoecology, doi: 10.1016/j.palaeo.2009.09.022

Johnson, J.S., Smellie, J.L., Nelson, A.E., Stuart, F.M. 2009. Did the Antarctic Peninsula Ice Sheet persist during interglacials? - evidence from cosmogenic dating of Pliocene lavas on James Ross Island. Global and Planetary Change, doi:10.1016/j.gloplacha.2009.09.001

Jones, D.S., Allmon, W.D. 1995. Records of upwelling, seasonality and growth in stable-isotope profiles of Pliocene mollusk shells from Florida. Lethaia, 28, 61-74.

Jones, D.S., Quitmyer, I.R. 1996. Marking time with bivalve shells: oxygen isotopes and season of annual increment formation. Palaios, 11, 340-346.

Jonkers, H.A. 1998a. Stratigraphy of Antarctic late Cenozoic pectinid-bearing deposits. Antarctic Science, 10, 161-170.

Jonkers, H.A. 1998b. The Cockburn Island Formation; Late Pliocene interglacial sedimentation in the James Ross Basin, northern Antarctic Peninsula. Newsletters on Stratigraphy, 36, 63-76.

Jonkers, H.A. 2003. Late Cenozoic-Recent Pectinidae (Mollusca: Bivalvia) of the Southern Ocean and neighbouring regions. Monographs of Marine Mollusca, 5, $125 \mathrm{pp}$.

Jonkers, H.A., Lirio, J.M., Dell Valle, R.A., Kelley, S.P. 2002. Age and environment of MiocenePliocene glaciomarine deposits, James Ross Island, Antarctica. Geological Magazine, 139, 577594.

Knowles, T., Taylor, P.D., Williams, M., Haywood, A.M., Okamura, B. 2009. Pliocene seasonality across the North Atlantic inferred from cheilostome bryozoans. Palaeogeography, Palaeoclimatology, Palaeoecology, 277, 226-235 
575

576

577

578

579

580

581

582

583

584

585

586

Krantz, D. E., Williams, D. F., Jones, D. S. 1987. Ecological and paleoenvironmental information using stable isotope profiles from living and fossil molluscs. Palaeogeography, Palaeoclimatology, Palaeoecology, 58, 249-266.

Leng, M.J., Marshall, J.D. 2004. Palaeoclimate interpretation of stable isotope data from lake sediment archives. Quaternary Science Reviews, 23, 811-831.

Levitus, S., Boyer, T.P. 1994. World Ocean Atlas 1994, vol. 4, Temperature, NOAA Atlas NESDIS, vol. 4, 129 pp., NOAA, Silver Spring, Md.

Lunt, D.J., Valdes, P.J., Haywood, A.M., Rutt, I. 2008. Closure of the Panama Seaway during the Pliocene - Implications for Climate and Northern Hemisphere Glaciation. Climate Dynamics, 30, 1-18. (doi:10.1007/s00382-007-0265-6).

McArthur, J.M., Rio, D., Massari, F., Castradori, D., Bailey, T.R., Thirlwall, M., Houghton, S. 2006. A revised Pliocene record for marine- ${ }^{87} \mathrm{Sr} /{ }^{86} \mathrm{Sr}$ used to date an interglacial event recorded in the Cockburn Island Formation, Antarctic Peninsula. Palaeogeography, Palaeoclimatology, Palaeoecology, 242, 126-136.

McConnaughey, T.A., Gillikin, D.P. 2008. Carbon isotopes in mollusk shell carbonates. GeoMarine Letters, doi:10.1007/s00367-008-0116-4.

McConnaughey, T.A., Burdett, J., Whelan, J.F., Paull, C.K. 1997. Carbon isotopes in biological carbonates: Respiration and photosynthesis. Geochimica et Cosmochimica Acta, 61, 611-622.

Meredith, M.P., Brandon, M.A., Wallace, M.I., Clarke, A., Leng, M.J., Renfrew, I.A., van Lipzig, N.P.M., King, J.C. 2008. Variability in freshwater balance of northern Marguerite Bay, Antarctic Peninsula: results from $\delta^{18}$ O. Deep Sea Research Part 2, 55, 309-322.

Nelson, A., Smellie, J., Williams, M., Zalasiewicz, J.A. 2008. Late Miocene marine trace fossils from James Ross Island. Antarctic Science, 20, 591-592.

Nelson, A.E., Smellie, J., Hambrey, M., Williams, M., Vautravers, M., McArthur, J., Regelous, M. 2009. Neogene glacigenic debris flows on James Ross Island, northern Antarctic Peninsula, and 
their implications for regional climate history. Quaternary Science Reviews, $601 \quad$ doi:10.1016/j.quascirev.2009.08.016

602 O'Neil, J.R., Clayton, R.N., Mayeda, T.K. 1969. Oxygen isotope fractionation in divalent metal 603 carbonates. Journal of Chemical Physics, 51, 5547-58

604 Owen, R., Kennedy, H., Richardson, C. 2002a. Experimental investigation into partitioning of 605 stable isotopes between scallop (Pecten maximus) shell calcite and sea water. Palaeogeography, 606 Palaeoclimatology, Palaeoecology, 185, 163-174.

607 Owen, R., Richardson, C., Kennedy, H. 2002b. The influence of shell growth rate on striae 608 deposition in the scallop Pecten maximus. Journal of the Marine Biological Association of the United Kingdom, 82, 621-623.

Pirrie, D., Crame, J.A., Riding, J.B., Butcher, A.R., Taylor, P.D. 1997. Miocene glaciomarine sedimentation in the northern Antarctic Peninsula region: the stratigraphy and sedimentology of the Hobbs Glacier Formation, James Ross Island. Geological Magazine, 134, 745-762. doi:

Rohling, E. J. 2000. Paleosalinity: Confidence limits and future applications, Marine Geology, 163, 1-11.

Rohling, E. J., Bigg, G.R. 1998. Paleo-salinity and $\delta^{18} \mathrm{O}$ : a critical assessment, Journal of Geophysical Research, 103, 1307-1318 
625

Schöne, B.R., Oschmann, W., Rössler, J., Freyre Castro, A.D., Houk, S.D., Kröncke, I, Dreyer, W., Janssen, R., Rumohr, H., Dunca, E. 2003. North Atlantic Oscillation dynamics recorded in shells of a long-lived bivalve mollusk. Geology, 31, 1037-40.

Schöne, B.R., Fiebig, J., Pfeiffer, M., Gless, R., Hickson, J., Johnson, A.L.A., Dreyer, W., Oschmann, W. 2005. Climate records from a bivalved Methuselah (Arctica islandica, Mollusca; Iceland). Palaeogeography, Palaeoclimatology, Palaeoecology, 228, 130-148.

Schmidt, G. A. 1998. Oxygen-18 variations in a global ocean model, Geophysical Research Letters, $25,1201-1204$.

Schmidt, G.A. 1999. Forward modelling of carbonate proxy data from planktonic foraminifera using oxygen isotope tracers in a global ocean model, Paleoceanography, 14, 482-497.

Schmidt, G.A., Bigg, G.R., Rohling, E.J. 1999. "Global Seawater Oxygen-18 Database". http://data.giss.nasa.gov/o18data/

Smellie, J.L., McArthur, J.M., McIntosh, W.C., Esser, R. 2006a. Late Neogene interglacial events in the James Ross Island region, northern Antarctic Peninsula, dated by Ar/Ar and Sr-isotope stratigraphy. Palaeogeography, Palaeoclimatology, Palaeoecology, 242, 169-187.

Smellie, J.L., Nelson, A.E., Williams, M. 2006b. Fire and ice: unravelling the climatic and volcanic history of James Ross Island, Antarctic Peninsula. Geology Today, 22, 220-226.

Smellie, J.L., Johnson, J.S., McIntosh, W.C., Esser, R., Gudmundsson, M.G., Hambrey, M.J., de Vries, B. Van Wyk. 2008. Six million years of glacial history recorded in the James Ross Island Volcanic Group, Antarctic Peninsula. Palaeogeography, Palaeoclimatology, Palaeoecology, 260, $122-148$.

Smellie, J.L., Haywood, A.M., Hillenbrand, C-D., Lunt, D.L., Valdes, P.J. 2009. Nature of the Antarctic Peninsula Ice Sheet during the Pliocene: geological evidence and modelling results compared. Earth-Science Reviews, 94, 79-94.

Whitehouse, M.J., Priddle, J., Symon, C. 1996. Seasonal and annual change in seawater temperature, salinity, nutrient and chlorophyll a distributions around South Georgia, South Atlantic. Deep Sea 
Research Part 1, 43, 425-443.

652 Whitehead, J.M., Bohaty, S.M. 2003. Pliocene summer sea surface temperature reconstruction using 653 silicoflagellates from Southern Ocean ODP Site 1165. Paleoceanography, 18, 1075, 654 doi:1029/2002PA000829.

655 Whitehead, J.M., Wotherspoon, S., Bohaty, S.M. 2005. Minimal Antarctic sea ice during the Pliocene. 656 Geology, 33, 137-140.

657 Witbaard, R. 1996. Growth variations in Arctica islandica L. (Mollusca): a reflection of hydrography658 related food supply. ICES Journal of Marine Science, 53, 981-987

659 Williams, M., Smellie, J., Johnson, J., Blake, D. 2006. Late Miocene Asterozoans (Echinodermata) 660 from the James Ross Island Volcanic Group. Antarctic Science, 18, 117-122.

661 Williams, M., Haywood, A.M., Harper, E.M., Johnson, A., Knowles, T., Leng, M.J., Lunt, D., 662 Okamura, B., Taylor, P., Zalasiewicz, J.A. 2009a. Pliocene climate and seasonality in North 663 Atlantic shelf seas. Philosophical Transactions of the Royal Society, London, Series A, 367, 85$664108($ doi:10.1098/rsta.2008.0224)

665 Williams, M., Nelson, A.E., Smellie, J.L., Leng, M.J., Jarram, D.R., Johnson, A.L.A., Haywood, 666 A.M., Peck, V.L., Zalasiewicz, J.A., Bennett, C.E., Schöne, B.R. 2009b. A high fidelity 667 molluscan climate record for the Weddell Sea for a warm interval of the Early Pliocene. 668 Workshop on Pliocene climate, Bordeaux, France, October $22^{\text {nd }}$ to $25^{\text {th }} 2009$. Abstract at: 669 http://www.plioclimworkshop.com/ 

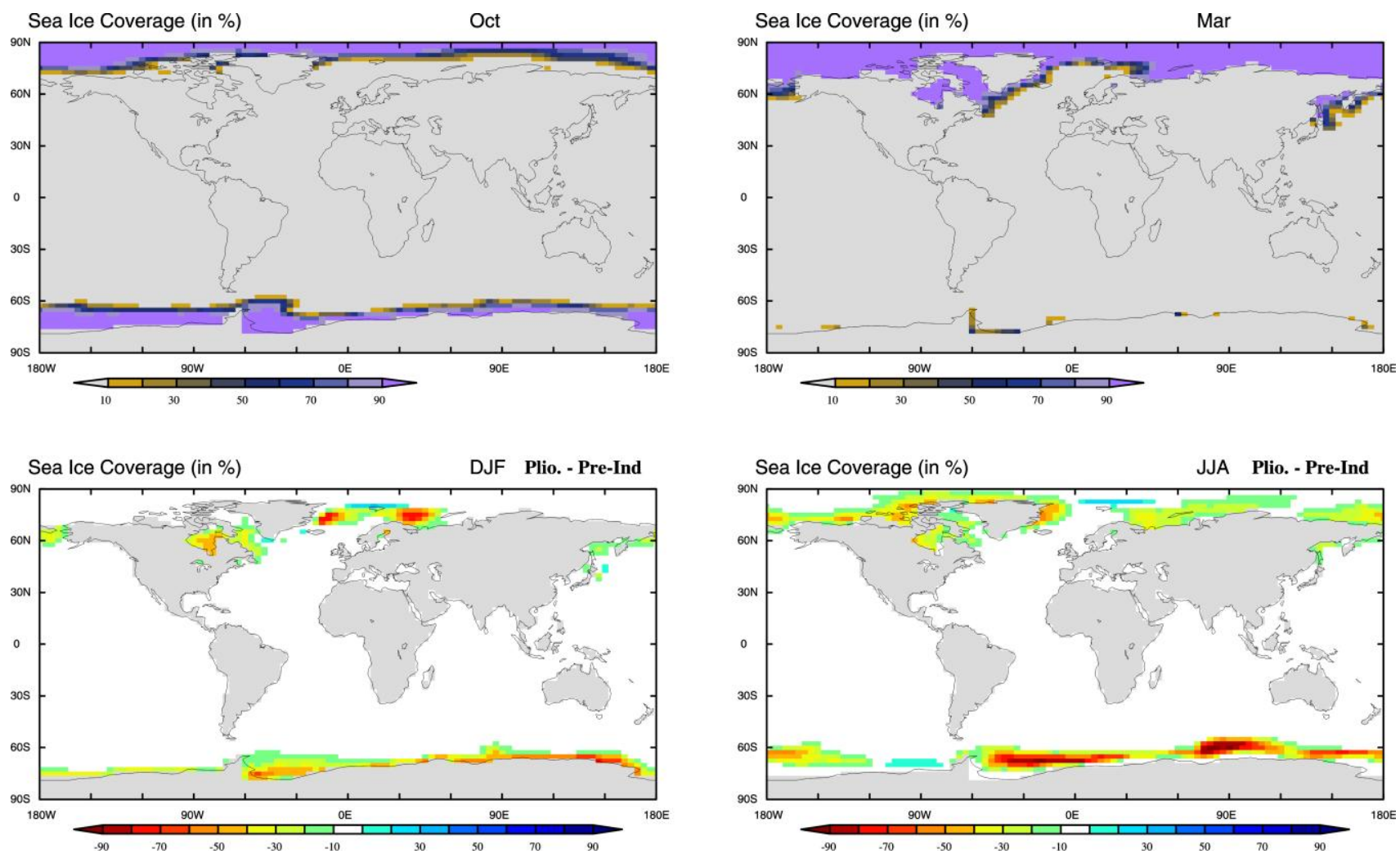

Fig. 1. Predictions of absolute sea-ice coverage (\%) for maximum (top left) and minimum sea-ice months (top right) in the Southern Hemisphere for the Early Pliocene (data from Lunt et al., 2008). The model predicts sea ice coverage in the northern Weddell Sea at $57^{\circ} \mathrm{W}$ and $64^{\circ} \mathrm{S}$ as $0.012 \%$ cover for late summer rising to $0.908 \%$ for late winter. Also shown are the differences between Early Pliocene and pre-industrial sea-ice cover as an average for the Southern Hemisphere summer (December, January and February [DJF; bottom left]) and winter seasons (June, July and August [JJA; bottom right]). Predictions from the Hadley Centre for Climate Research fully coupled ocean-atmosphere General Circulation Model version 3 (HadCM3). 

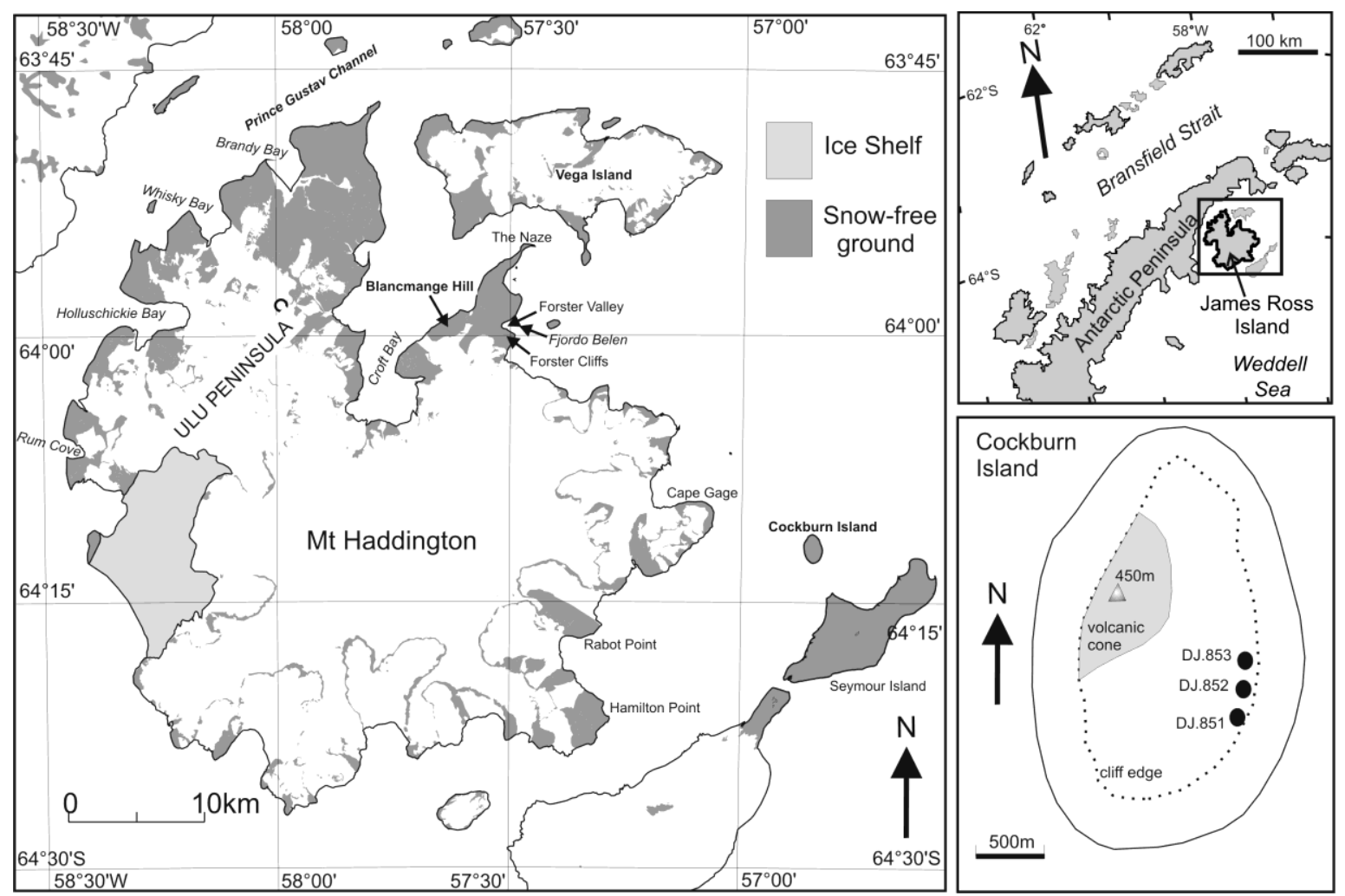

Cockburn

Island

N

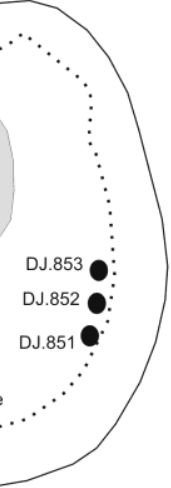

684

Fig. 2. Geographical location of James Ross Island on the northern Antarctic Peninsula (top right) and Cockburn Island (see main map to the left). Mollusc material for geochemical and morphological analysis mentioned here is sourced from three localities on the east side of Cockburn Island (map bottom right, localities DJ.851, DJ.852 and DJ.853 of H.A. Jonkers 1996, for which see Ross Island, for example at northwest Forster cliffs. 


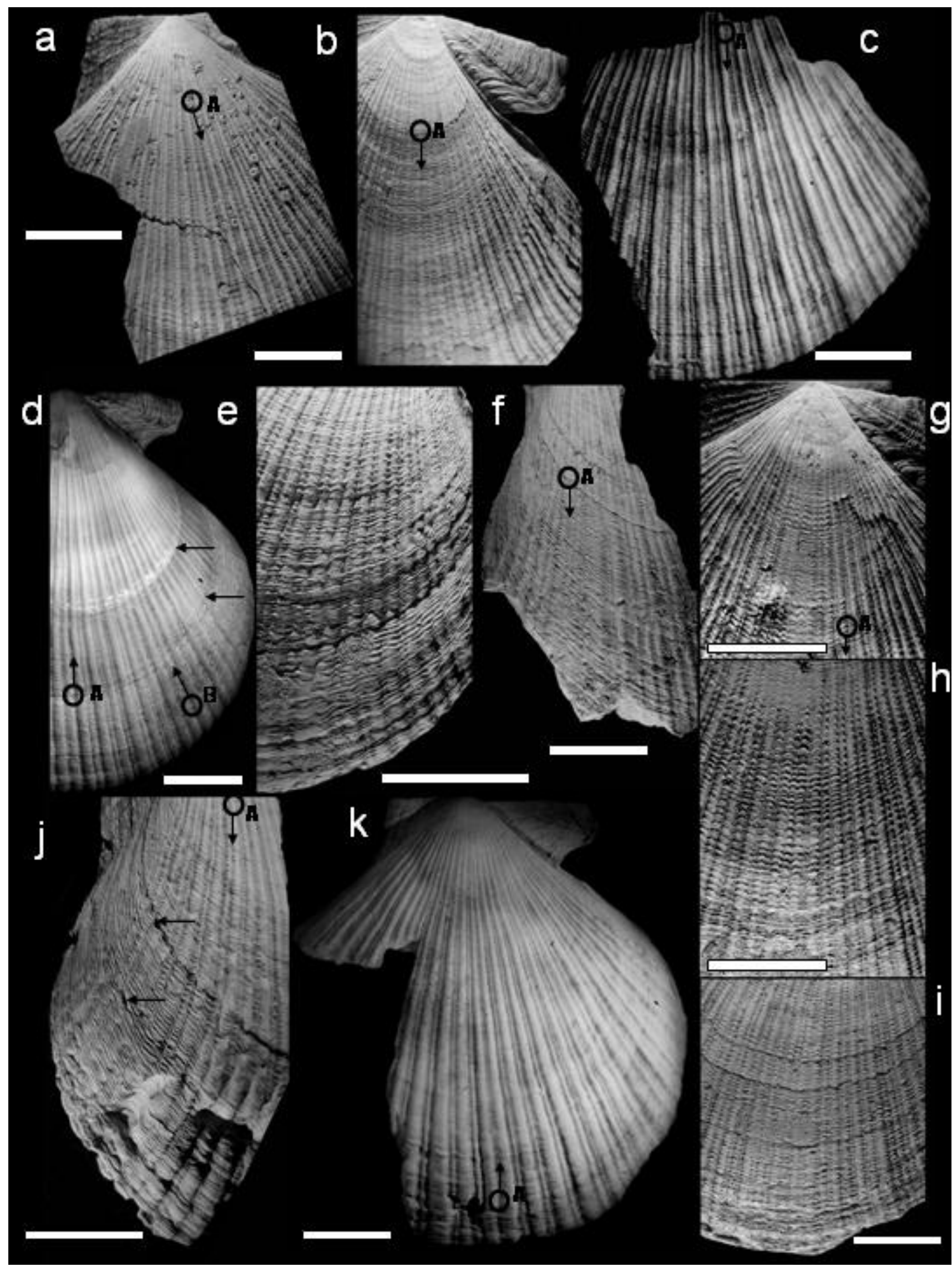

693 Fig. 3. Morphology of the bivalve Austrochlamys. The images are annotated with open circles

694 (labelled 'A' or 'B') to show points on the shell for cross reference with Figures 4 and 6. The arrow 
points in the direction where increments were measured. Also arrowed are major growth lines on two of the shells for comparison with the growth/isotope profiles shown in Figure 6. a, right valve, British Antarctic Survey (BAS) DJ.851.8. b, e, right valve, DJ.851.1. c, unnumbered specimen in BAS collection. d, right valve, DJ.853.1. f, left valve, DJ.852.22. g-i, right valve, DJ.851.3. j, right valve, DJ.851.159: bottom right part of image shows damage to the shell possibly as a response to disturbance by a predator. k, right valve, DJ.852.1. All specimens were collected from Cockburn Island by H.A. Jonkers and S.L. White in 1996 (see Fig. 2 for localities) except c, which was collected from surface scree by M. Williams and M. Laidlaw in 2006. Scale bars are $2 \mathrm{~cm}$.
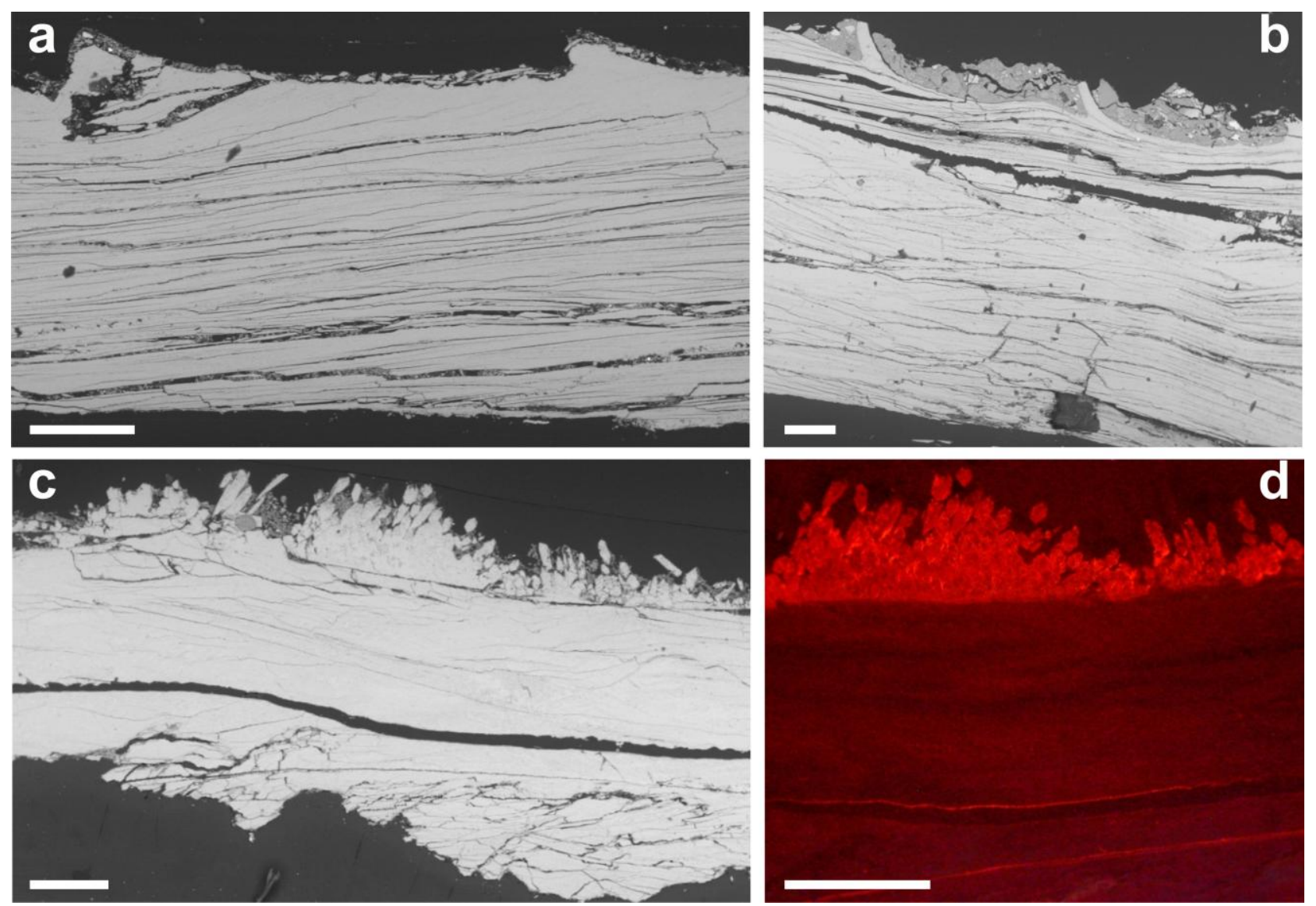

Fig. 4. SEM images of polished thin sections of two specimens of Pliocene Austrochlamys from the

Antarctic Peninsula (a, b). Both images show the well preserved foliated structure of the bivalve shell, but with a thin layer of sediment adhering to the outer surface that was removed prior to geochemical analysis. A specimen with an external diagenetic overgrowth cement of calcite crystals, from the same locality is shown in (c) SEM image, and (d) cathodoluminescence image. 
710 The diagenetic cement is brightly luminescent, while the shell foliae are weakly luminescent. Scale

711 bars are $0.25 \mathrm{~mm}$.

712
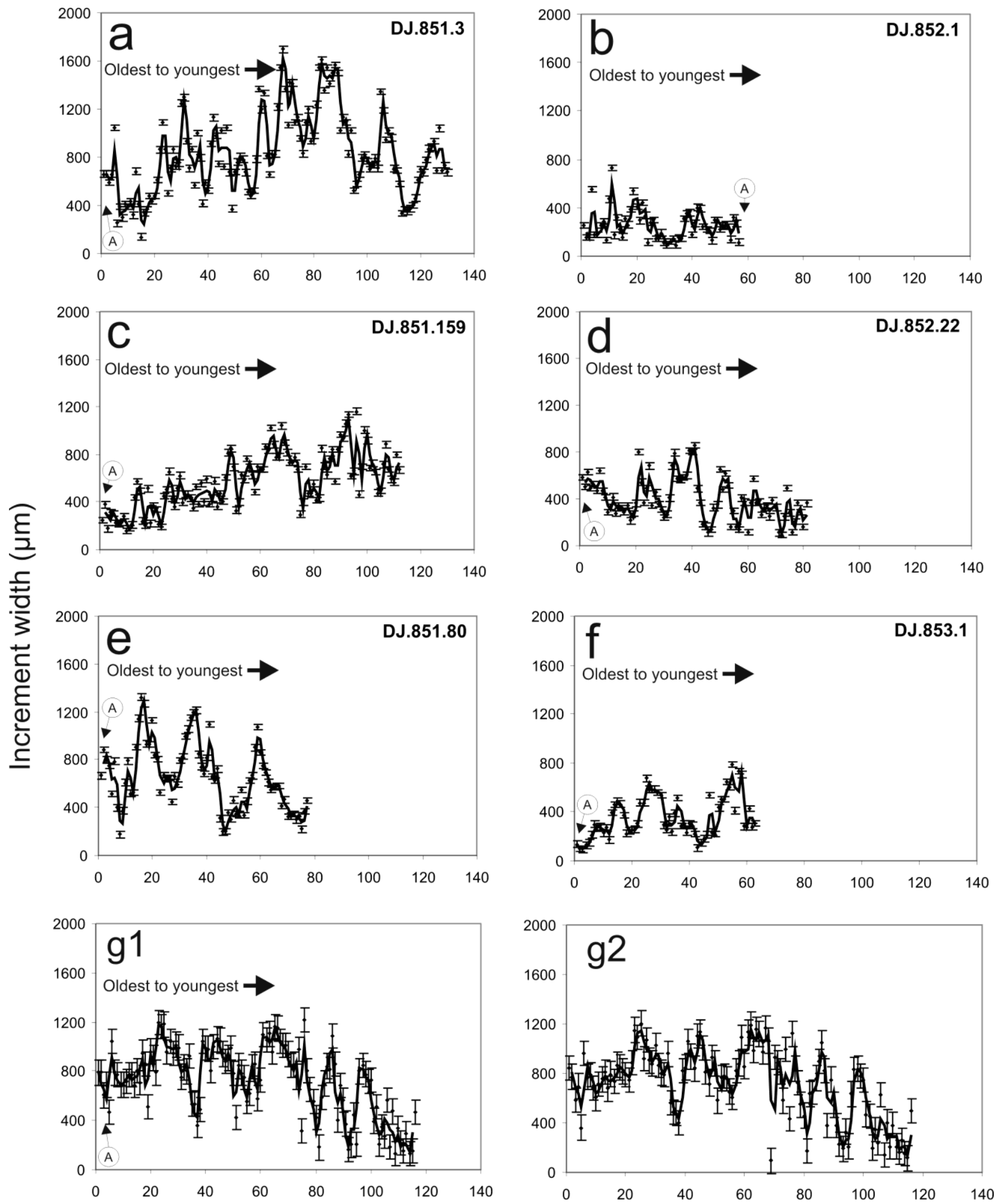

714 Fig. 5. Growth increment analysis of bivalves from the Cockburn Island Formation. Graphs a-f 
715 show growth increments plotted for areas of bivalve shells shown in Figure 3 ('A' denotes points on

716 the shell for cross-reference). Graphs g1 and g2 show repeat measurements for one shell (Fig. 3c)

717 demonstrating the accuracy of measurements that can be achieved with Panopea. Vertical scale is $718 \mu \mathrm{m}$, horizontal scale is growth increment measured from oldest (1) to youngest. In addition to the 719 shells plotted here, over 200 increments measured for shell DJ.851.1 show a similar pattern of high720 frequency growth variation.
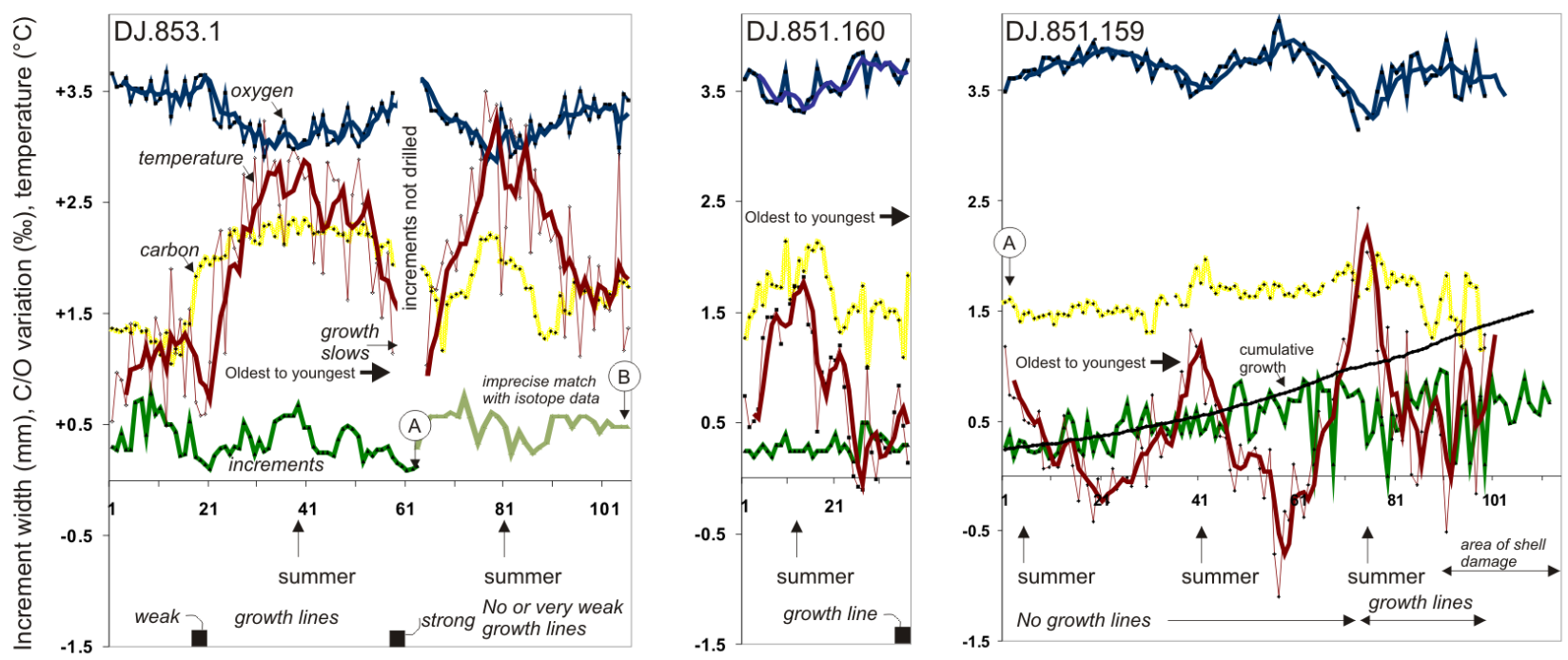

Fig. 6. Seasonality recorded in the bivalves DJ.851.159, DJ.851.160 and DJ.853.1 from the Cockburn Island Formation. The figure plots $\delta^{13} \mathrm{C}$ (yellow) and $\delta^{18} \mathrm{O}$ (blue) as per mil variation (left hand vertical scale). Also shown is temperature (red, left hand scale in ${ }^{\circ} \mathrm{C}$ ) reconstructed using a $\delta^{18} \mathrm{O}_{\mathrm{sw}}$ value of $-0.2 \%$ and the $\mathrm{O}^{\prime}$ Neil et al. (1969) equation $\left[\mathrm{T}=16.9-4.38\left(\delta^{18} \mathrm{O}_{\mathrm{c}}-\delta^{18} \mathrm{O}_{\mathrm{sw}}\right)+\right.$ $\left.0.10\left(\delta^{18} \mathrm{O}_{\mathrm{c}}-\delta^{18} \mathrm{O}_{\mathrm{sw}}\right)^{2}\right]$; thick red line is the 3-point running average of the temperature reconstruction. The horizontal scale records growth increment number (oldest to left). For all bivalves incremental growth (3-point running average, green, see left hand scale $\mathrm{mm}$ variation) is also plotted as is cumulative growth (black line, scale not shown) in bivalve DJ.851.159. 'A' and ' $\mathrm{B}$ ' denote a point on the shell for cross-reference with Figure 3. Also marked are growth lines, with annotation where these may relate to damage (disturbance) on shell DJ.851.159. Precise matching of growth increment measurements with increments drilled for isotopes is not possible, but in most 
734

cases we have achieved a match in the data of \pm 2 to 3 increments. In shell DJ.853.1 the match between incremental growth and stable isotope values is less precise beyond increment 62 (as indicated by the change to light green colour for the increments).

\begin{tabular}{|c|c|c|c|c|c|c|c|c|c|c|c|}
\hline $\begin{array}{c}\text { Modern } \\
\text { northern } \\
\text { Weddell } \\
\text { Sea } \\
\text { seasonality }\end{array}$ & \begin{tabular}{|c|} 
Pliocene \\
Modelled \\
seasonality \\
(depth 0- \\
$5 \mathrm{~m}$ )
\end{tabular} & $\begin{array}{l}\text { Pliocene } \\
\text { Modelled } \\
\text { seasonality } \\
\text { (depth 95- } \\
113 \mathrm{~m})\end{array}$ & $\begin{array}{c}\text { Bivalve } \\
\text { DJ.851.159 } \\
\text { (ס180sw of } \\
-0.2 \% \text { ) }\end{array}$ & $\begin{array}{c}\text { Bivalve } \\
\text { DJ.851.159 } \\
(\bar{\delta} 180 \text { sw of } \\
-0.2 \% \text { ) } \\
\text { Craig } \\
\text { equation }\end{array}$ & $\begin{array}{c}\text { Bivalve } \\
\text { DJ.851.159 } \\
(\delta 180 s w \\
\text { variable } \\
\text { from } 0 \text { to } \\
-0.4 \%)\end{array}$ & $\begin{array}{c}\text { Bivalve } \\
\text { DJ.851.160 } \\
\text { (ס180sw of } \\
-0.2 \% \text { ) }\end{array}$ & $\begin{array}{c}\text { Bivalve } \\
\text { DJ.851.160 } \\
(\delta 180 \text { sw of } \\
-0.2 \%) \\
\text { Craig } \\
\text { equation }\end{array}$ & $\begin{array}{c}\text { Bivalve } \\
\text { DJ.851.160 } \\
(\delta 180 \text { sw } \\
\text { variable } \\
\text { from } 0 \text { to } \\
-0.4 \% \text { ) }\end{array}$ & $\begin{array}{c}\text { Bivalve } \\
\text { DJ.853.1 } \\
(\delta 180 \text { sw of } \\
-0.2 \% \text { o })\end{array}$ & $\begin{array}{c}\text { Bivalve } \\
\text { DJ.853.1 } \\
(\delta 180 \text { sw of } \\
-0.2 \%) \\
\text { Craig } \\
\text { equation }\end{array}$ & $\begin{array}{c}\text { Bivalve } \\
\text { DJ.853.1 } \\
\text { ( } \delta 180 \text { sw } \\
\text { variable } \\
\text { from } 0 \text { to } \\
-0.4 \% \text { ) }\end{array}$ \\
\hline-0.1 to 1.99 & -1.7 to 3.08 & -0.69 to -0.52 & -1.1 to 2.5 & -0.3 to 2.8 & -0.4 to 2 & -0.1 to 1.8 & 0.6 to 2.3 & 0.6 to 1.1 & 0.5 to 3.5 & 1.1 to 3.7 & 1.2 to 2.8 \\
\hline 2.09 & 4.78 & 0.17 & 3.6 & 3.1 & 2.4 & 1.9 & 1.7 & 0.5 & 3 & 2.6 & 1.6 \\
\hline
\end{tabular}

Table 1. Reconstructed sea temperatures from the Cockburn Island Formation bivalves compared with modern and modelled Early Pliocene sea temperature seasonality in the northern Weddell Sea. Modern temperature variation is from Whitehouse et al. (1996), modelled Early Pliocene data is from Lunt et al. (2008). Both temperature maxima and minima and total temperature range are shown. Temperature calculations for 'Craig (1965)' use the form of this equation given in Leng and Marshall (2004) $\left[\mathrm{T}=16-4.14\left(\delta^{18} \mathrm{O}_{\mathrm{c}}-\delta^{18} \mathrm{O}_{\mathrm{sw}}\right)+0.13\left(\delta^{18} \mathrm{O}_{\mathrm{c}}-\delta^{18} \mathrm{O}_{\mathrm{sw}}\right)^{2}\right]$ and a $\delta^{18} \mathrm{O}_{\mathrm{sw}}$ value of $-0.2 \%$.

Appendix 1. Model calculated values for the $\delta^{18} \mathrm{O}$ of seawater are an attempt to capture longitudinal and latitudinal change as a function of climate, and are based on precipitation minus evaporation $(\mathrm{P}-\mathrm{E})$ estimates derived from the GCM. Present-day observed $\delta^{18} \mathrm{O}_{\mathrm{sw}}$ [Bigg and Rohling, 2000; Schmidt, 1998, 1999; G. A. Schmidt et al., 1999, Global seawater oxygen-18 database, available at http://data.giss.nasa.gov/o18data/] is calibrated against observed $\mathrm{P}-\mathrm{E}$ (ECMWF reanalysis data) for the Atlantic Ocean. The resulting formulae (see below) are used to predict $\delta^{18} \mathrm{O}_{\mathrm{sw}}$.

\section{Atlantic Calibration:}

$$
\delta^{18} \mathrm{O}_{\mathrm{sw}}=0.24-0.008(\mathrm{P}-\mathrm{E}) \mathrm{r} 2=0.7
$$


$758 \quad \mathrm{P}-\mathrm{E}$ is given in units of $\mathrm{cm} \mathrm{yr}-1$.

759

760 Although this is a useful approach, care must be taken when examining the results since they are

761 based solely on the model's predictions of $\mathrm{P}-\mathrm{E}$, where in reality the $\delta^{18} \mathrm{O}_{\mathrm{sw}}$ is also dependent upon

762 mixing because of ocean currents, runoff, etc. The resulting correlation for the Atlantic Ocean

$763 \delta^{18} \mathrm{O}_{\text {sw }}$ to $\mathrm{P}-\mathrm{E}$ is reasonable. In addition to $\mathrm{P}-\mathrm{E}$ we calibrated $\delta^{18} \mathrm{O}_{\text {sw }}$ against salinity [Levitus and 764 Boyer, 1994]. This increased the r2 value to 0.9 for the Atlantic but Haywood et al. (2007) 765 demonstrated that this did not significantly change the diagnostic predictions of $\delta^{18} \mathrm{O}_{\mathrm{sw}}$ generated 766 using $\mathrm{P}-\mathrm{E}$ for the Pliocene.

767 Nevertheless, it is important to recognise that the use of a salinity: $\delta^{18} \mathrm{O}$ or P $-\mathrm{E}: \delta^{18} \mathrm{O}$ co768 variation from present-day observations as a diagnostic for the $\delta^{18} \mathrm{O}$ composition of seawater is 769 complicated by the fact that temperature gradients are steeper today than they were during the 770 Miocene and Pliocene (a reflection of cooler temperatures in polar regions today) which will result 771 in different patterns of Rayleigh distillation and hence different $\delta^{18} \mathrm{O}$ values in the hydrological 772 cycle [Rohling and Bigg, 1998; Rohling, 2000]. 